\title{
The effect of cottonseed condensed tannins on the ileal digestibility of amino acids in casein and cottonseed kernel
}

\author{
BY FENG YU, P. J. MOUGHAN* AND T. N. BARRY \\ Department of Animal Science, Massey University, Palmerston North, New Zealand
}

(Received 5 April 1995 - Revised 10 July 1995 - Accepted 16 August 1995)

\begin{abstract}
The effect of adding cottonseed hulls to casein- and cottonseed-kernel-based diets on the apparent and true ileal digestibility of $\mathbf{N}$ and amino acids, and the proportion of this effect accounted for by condensed tannin (CT), were determined using the growing rat. Sixty rats were allocated randomly to ten semipurified diets, containing either casein (four diets) or purified unheated solvent-extracted cottonseed kernel (six diets) as the sole protein source, with $\mathrm{Cr}_{2} \mathrm{O}_{3}$ added as an indigestible marker. Two of the casein diets contained no hulls whilst the remaining two diets contained $70 \mathrm{~g}$ cottonseed hulls $/ \mathrm{kg}$. Two of the cottonseed-kernel-based diets contained no hulls, with two containing $23 \mathrm{~g}$ hulls/kg and the remaining two containing $46 \mathrm{~g}$ hulls/kg. For each pair of diets, PEG was either included or excluded. The effect of CT was quantified by comparing control rats (-PEG; CT acting) with PEG-supplemented rats (+ PEG; CT inactivated) at each level of dietary hulls. The rats were given their respective experimental diets for $14 \mathrm{~d}$. Each rat was given the food ad libitum for $10 \mathrm{~min}$ hourly from 08.00 to 18.00 hours. On day 14, samples of digesta were collected at death from the terminal $150 \mathrm{~mm}$ of ileum at $7 \mathrm{~h}$ from the first meal. Apparent and true ileal digestibilities were calculated for DM, N and the individual amino acids. The principal finding was that the inclusion of hulls depressed the apparent and true ileal digestibilities of $\mathbf{N}$ and amino acids, but with the response differing between diets. With the casein-based diet the mean apparent and true ileal amino acid digestibilities were significantly depressed from 0.89 and 0.96 to 0.85 and 0.92 respectively, by the inclusion of $70 \mathrm{~g}$ hulls $/ \mathrm{kg}$ in the diet, and addition of PEG then restored these to 0.89 and 0.95 . All of the depression could be explained by the CT content of the hulls. However, with the cottonseed-kernel-based diet the responses fell into three categories. The apparent and true ileal digestibilities of the essential amino acids cystine and methionine were not affected by hull addition, ileal digestibilities of leucine, isoleucine, lysine, threonine and valine were markedly depressed by hull addition with approximately $50 \%$ of the depression being explained by $\mathrm{CT}$, whilst the ileal digestibilities of histidine, arginine and phenylalanine were depressed by hull addition but little or none of this effect could be explained by CT. Thus the effect of hulls on protein digestion clearly differed with source of protein. With the cottonseed-kernel-based diet it seems that components of the hulls other than CT also depressed the apparent and true ileal digestibilities of $\mathrm{N}$ and amino acids. The identity of these components is unknown.
\end{abstract}

Cottonseed: Condensed tannin: Ileal digestibility

Cottonseed meal is an important source of protein for single-stomached farm animals (Lusas \& Jividen, 1987), but is regarded as being of variable quality and generally of low amino acid availability (Batterham et al. 1990; Batterham, 1992). The nutritional value of cottonseed meal is influenced by the processing conditions applied to cottonseed during oil extraction, and by the presence of antinutritional factors and NSP (Frank, 1987; Huisman et al. 1990; Yu et al. 1993). Gossypol, a naturally-occurring polyphenolic substance in cottonseed, reacts with the $\epsilon$-amino group of lysine during heating of the seed to form insoluble, indigestible complexes (Lyman et al. 1959; Damaty \& Hudson, 1979; Berardi \&

* For reprints. 
Goldblatt, 1980; Ikurior \& Fetuga, 1988). Other components of the seed, such as asparagine and glutamine (Varnish \& Carpenter, 1975), raffinose and phospholipids (Martinez et al. 1967), have been found to interact during seed processing, leading to interand intramolecular cross-linkages, which reduce protein digestibility by obstructing enzymic attachment (Varnish \& Carpenter, 1975).

Recent studies have found that condensed tannins (CT) are present in commercially produced cottonseed meal in significant concentrations $(8-16 \mathrm{~g} / \mathrm{kg}$ DM; Balogun et al. 1990; Terrill et al. 1992; Yu et al. 1993). CT occur in cottonseed hulls (32-65 g/ $\mathrm{kg} \mathrm{DM})$ mainly bound to protein and fibre, but are absent from cottonseed kernel (Yu et al. 1993). CT are polyphenolic compounds, capable of precipitating proteins from aqueous solutions, and hence have been shown to have antinutritional effects in non-ruminant animals (Huisman et al. 1990; Helsper et al. 1993). Specifically, they are known to increase faecal excretion of nutrients, particularly amino acids, thus reducing apparent nutrient digestibility (Mangan, 1988; Salunkhe et al. 1990). Moreover, in vitro and in vivo studies have demonstrated that CT can inhibit the activity of digestive enzymes (Longstaff \& McNab, 1991; Jansman, 1993 b) due to the formation of tannin-enzyme complexes which are biologically inactive (Griffiths, 1979; Griffiths \& Moseley, 1980). In the rat, sorghum and faba bean CT are known to cause hypertrophy of the parotid glands, accompanied by an increased secretion of proline-rich proteins (Mehansho et al. 1983, 1992; Jansman, 1993 b). CT may cause damage to the gut mucosa (Mitjavila et al. 1977; van Leeuwen et al. 1993), and may also cause an increased loss of mucin in the faeces (Sell et al. 1985).

There is no information on the effects of bound CT in cottonseed hulls on nutrient digestibility in single-stomached animals. The objective of the present study was to determine the effect of CT in cottonseed hulls on the apparent and true ileal digestibilities of amino acids in casein and in unheated solvent-extracted cottonseed kernel fed to the growing rat. Dietary PEG addition was used in the present work to allow an effect of the CT, consequent on an increase in the level of dietary inclusion of cottonseed hulls, to be distinguished from an effect of the increased fibre. PEG binds strongly to CT and can be used to displace protein completely from the CT-protein complexes (Jones \& Mangan, 1977; Barry \& Manley, 1986). Work was also conducted to demonstrate that adding PEG to the diet had no effect on protein digestion in the absence of CT.

\section{MATERIALS AND METHODS}

Preparation of cottonseed kernel and hulls

Delinted whole cottonseed (var. Siokra L22) supplied by Cotton Seed Distributors Ltd, Wee Waa, NSW, Australia was cracked using a crushing-mill (AB Thorell and Persson, Uppsala, Sweden), and separated into kernels and hulls using air-flow, at the Seed Technology Centre, Massey University, with final manual separation. The separated kernels were freeze-dried for $48 \mathrm{~h}$, ground to pass a $2 \mathrm{~mm}$ diameter sieve, and the oil and gossypol were extracted using hexane and then acetone-water $(70: 30, \mathrm{w} / \mathrm{w})$ using a modification of the Pons \& Eaves (1967) procedure, as described by Yu et al. (1995a). Finally, extracted cottonseed kernel and hulls were then re-ground to pass through a $1 \mathrm{~mm}$ diameter sieve and were stored at $-20^{\circ}$. The chemical compositions of the unheated solvent-extracted cottonseed kernel and hulls are shown in Table 1.

\section{Animals and diets}

Male and female Sprague-Dawley rats, which had been weaned at 4 weeks of age, were reared on a high quality diet at the Small Animal Production Unit, Massey University. The 
Table 1. Chemical compositions $(\mathrm{g} / \mathrm{kg} \mathrm{DM})$ of the unheated solvent-extracted cottonseed kernel and hulls

(Mean values from duplicate determinations)

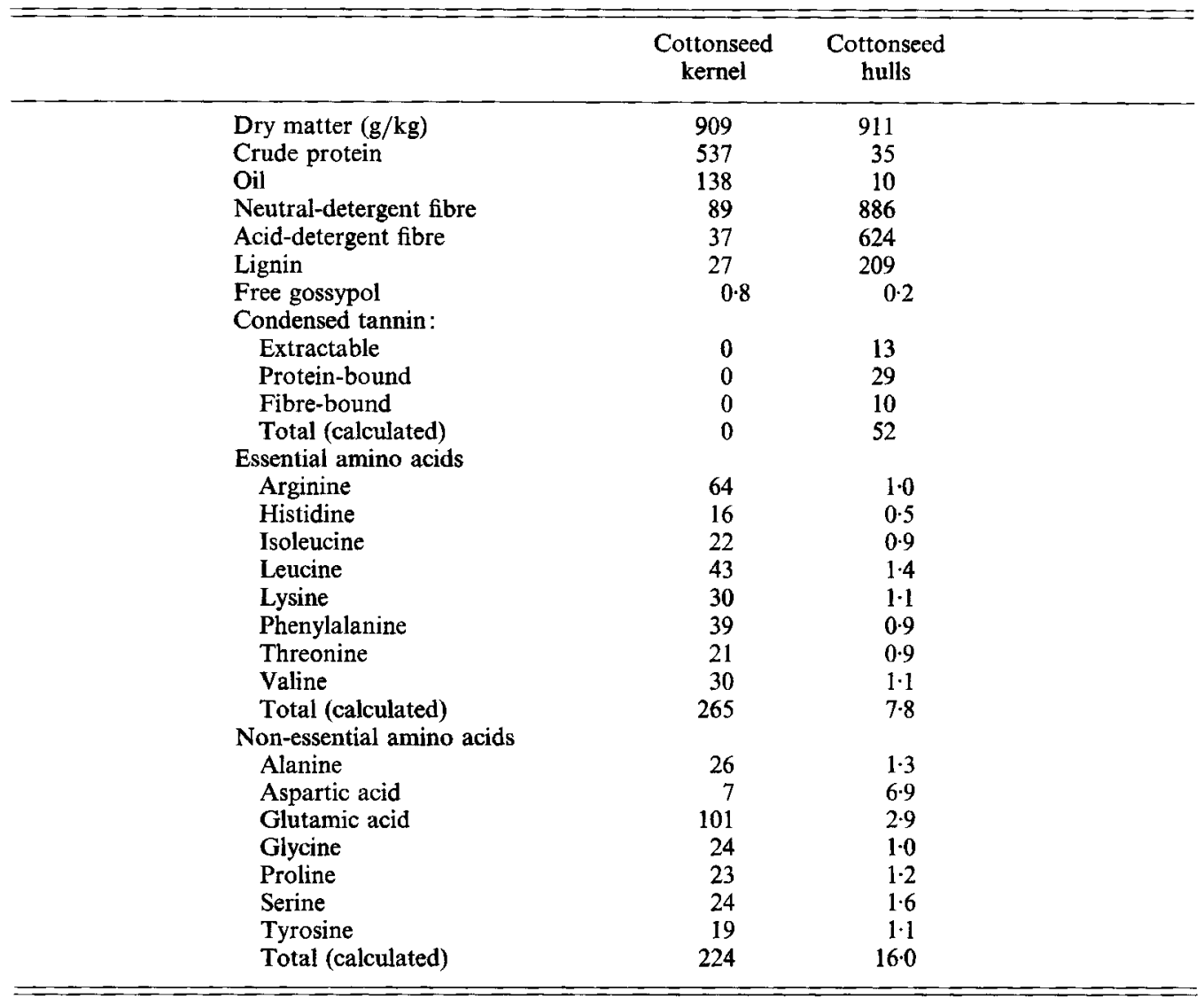

animals were kept individually in raised stainless steel cages with wire mesh floors, at $20 \pm 2^{\circ}$ and with a $12 \mathrm{~h}$ light-dark cycle.

Ten semi-purified diets were formulated based on maize starch, and containing either casein or purified unheated solvent-extracted cottonseed kernel as the sole protein source (Table 2). The diets contained graded levels of cottonseed hulls, and $\mathrm{Cr}_{2} \mathrm{O}_{3}$ was added as an indigestible marker compound to all diets. At each level of dietary hulls, PEG (molecular weight 3500, Union Carbide, Danbury, CT, USA) was either included or excluded. Thus, the effect of CT could be quantified by comparing control rats (-PEG; CT acting) with PEG-supplemented rats (CT inactivated) at each level of dietary hulls. The PEG was added at a minimum level of $2 \mathrm{mg} / \mathrm{mg}$ total CT to maximize the displacement of protein from the CT-protein complexes (Yu et al. 1995b).

\section{Experimental procedure}

Sixty rats (body weight 176 (SE 4.5) g) were assigned randomly to the ten experimental diets (Table 2), such that there were three males and three females per diet. The animals were initially fed on a casein-based diet (approximately $100 \mathrm{~g}$ crude protein $/ \mathrm{kg}$ ) for $2 \mathrm{~d}$ and were 
Table 2. Ingredient ( $\mathrm{g} / \mathrm{kg}$ air-dry weight) and chemical compositions of the casein and unheated solvent-extracted cottonseed-kernel-based diets

\begin{tabular}{|c|c|c|c|c|c|c|c|c|c|c|}
\hline \multirow{3}{*}{$\begin{array}{l}\text { Diet... } \\
\text { Cottonseed hulls... } \\
\text { PEG*... }\end{array}$} & \multicolumn{4}{|c|}{ Casein } & \multicolumn{6}{|c|}{ Cottonseed kernel } \\
\hline & \multicolumn{2}{|c|}{$0 \mathrm{~g} / \mathrm{kg}$} & \multicolumn{2}{|c|}{$70 \mathrm{~g} / \mathrm{kg}$} & \multicolumn{2}{|c|}{$0 \mathrm{~g} / \mathrm{kg}$} & \multicolumn{2}{|c|}{$23 \mathrm{~g} / \mathrm{kg}$} & \multicolumn{2}{|c|}{$46 \mathrm{~g} / \mathrm{kg}$} \\
\hline & - & + & - & + & - & + & - & + & - & + \\
\hline \multicolumn{11}{|l|}{ Ingredient } \\
\hline Casein & 160 & 160 & 160 & 160 & - & - & - & - & - & - \\
\hline Cottonseed kernel & - & - & - & - & 290 & 290 & 290 & 290 & 290 & 290 \\
\hline Cottonseed hulls & - & - & 70 & 70 & - & - & 23 & 23 & 46 & 46 \\
\hline PEG* & - & 8 & - & 8 & - & 5 & - & 2.5 & - & 5 \\
\hline Maize starch & 599 & 591 & 529 & 521 & 469 & 464 & 446 & 443.5 & 423 & 418 \\
\hline Sucrose & 100 & 100 & 100 & 100 & 100 & 100 & 100 & 100 & 100 & 100 \\
\hline Maize oil & 50 & 50 & 50 & 50 & 50 & 50 & 50 & 50 & 50 & 50 \\
\hline Cellulose & 35 & 35 & 35 & 35 & 35 & 35 & 35 & 35 & 35 & 35 \\
\hline Mineral/vitamin premix & 15 & 15 & 15 & 15 & 15 & 15 & 15 & 15 & 15 & 15 \\
\hline Sodium chloride & 5 & 5 & 5 & 5 & 5 & 5 & 5 & 5 & 5 & 5 \\
\hline Magnesium sulphate & 2 & 2 & 2 & 2 & 2 & 2 & 2 & 2 & 2 & 2 \\
\hline Potassium carbonate & 4 & 4 & 4 & 4 & 4 & 4 & 4 & 4 & 4 & 4 \\
\hline Dicalcium phosphate & 24 & 24 & 24 & 24 & 24 & 24 & 24 & 24 & 24 & 24 \\
\hline Chromic oxide & 6 & 6 & 6 & 6 & 6 & 6 & 6 & 6 & 6 & 6 \\
\hline \multicolumn{11}{|l|}{ Nutrient content (DM basis) $\S$} \\
\hline DM & 983 & 982 & 977 & 984 & 973 & 971 & 971 & 975 & 966 & 975 \\
\hline $\mathrm{OM}$ & 951 & 945 & 950 & 949 & 924 & 927 & 926 & 922 & 927 & 931 \\
\hline Crude protein & 150 & 156 & 162 & 156 & 160 & 160 & 163 & 161 & 169 & 165 \\
\hline Oil & 17 & 20 & 20 & 15 & 94 & 94 & 91 & 94 & 93 & 91 \\
\hline NDF & $\ldots$ & - & 61 & 61 & 26 & 26 & 46 & 46 & 67 & 67 \\
\hline ADF & - & $\ldots$ & 43 & 43 & 11 & 11 & 25 & 25 & 39 & 39 \\
\hline Lignin & - & - & 14 & 14 & 8 & 8 & 13 & 13 & 18 & 18 \\
\hline Gross energy ( $\mathrm{MJ} / \mathrm{kg}$ ) & 18 & 18 & 18 & 18 & 18 & 19 & 19 & 19 & 19 & 19 \\
\hline & - & - & - & - & 174 & 182 & 175 & 189 & 184 & 186 \\
\hline \multicolumn{11}{|l|}{ Condensed tannin $(\mathrm{g} / \mathrm{kg})$} \\
\hline Total & 0 & 0 & 3.6 & 3.6 & 0 & 0 & $1 \cdot 2$ & $1 \cdot 2$ & $2 \cdot 4$ & $2 \cdot 4$ \\
\hline Free & 0 & 0 & 0.91 & 0.91 & 0 & 0 & 0.30 & $0 \cdot 30$ & 0.60 & 0.60 \\
\hline
\end{tabular}

OM, organic matter; NDF, neutral-detergent fibre; $\mathrm{ADF}$, acid-detergent fibre.

* MW 3500 .

$\dagger$ Avicel, Asahi Chemical Industry Company Ltd, Tokyo, Japan.

\$ Rat Pellet Premix 9327, Technik Products, Auckland, New Zealand. Supplied the following per kg diet: $3 \mathrm{mg}$ retinol, $0.04 \mathrm{mg}$ cholecalciferol, $30 \mathrm{mg} \alpha$-tocopherol, $1 \mathrm{mg}$ menadione, $1 \mathrm{mg}$ thiamin, $4 \mathrm{mg}$ riboflavin, $3 \mathrm{mg}$ pyridoxine, $0.02 \mathrm{mg}$ cyanocobalamin, $15 \mathrm{mg}$ pantothenic acid, $1 \mathrm{mg}$ pteroylmonoglutamic acid, $25 \mathrm{mg}$ niacin, $125 \mathrm{mg}$ antioxidant, $250 \mathrm{mg}$ choline, $100 \mathrm{mg}$ manganese, $35 \mathrm{mg}$ iron, $10 \mathrm{mg}$ copper, $60 \mathrm{mg}$ zinc, $1 \mathrm{mg}$ cobalt, $0 \cdot 15 \mathrm{mg}$ selenium.

$\S$ Means of duplicate determinations.

then given the experimental diets for a further $14 \mathrm{~d}$. The diets were offered in stainless-steel feeders with anti-spill devices similar to those described by Thomsen (1981). The rats were trained to consume their experimental diet between 08.00 and 18.00 hours with the feeder being placed in the cage for $10 \mathrm{~min}$ at hourly intervals. The training was achieved within $7 \mathrm{~d}$, and feed intakes were recorded after each $10 \mathrm{~min}$ feeding. Fresh water was freely available.

On day 14 the rats were asphyxiated in $\mathrm{CO}_{2}$ gas and decapitated (immediately ceasing all neural stimulation to the gut) at $7 \mathrm{~h}$ from the start of feeding. The abdomen was opened by an incision along the mid-ventral line and the skin and musculature were folded back to expose the viscera. The final $150 \mathrm{~mm}$ of the ileum was immediately dissected from the body, 
and the intestinal surface cleaned using absorbent tissue paper, taking care not to apply pressure to the intestine. The digesta were slowly flushed out into plastic bags with distilled water from a plastic syringe. The digesta from each animal were kept separate and packed in ice immediately after collection.

Ileal digesta and samples of the test diets were subsequently freeze-dried, finely ground and stored at $-20^{\circ}$ for the determination of $\mathrm{N}, \mathrm{Cr}$, and total amino acids. The stomach contents were inspected for signs of faecal contamination resulting from coprophagy.

\section{Chemical analysis}

The diets and ileal digesta were analysed in duplicate for total $\mathbf{N}$ using the Kjeldahl procedure, and crude protein was calculated as total $\mathrm{N} \times 6.25$. The $\mathrm{Cr}$ contents of duplicate $15 \mathrm{mg}$ samples of ileal digesta and each diet were determined by the method of Costigan \& Ellis (1987). The CT contents of the diets were determined using the method of Terrill et al. (1992). Free gossypol in the diets was estimated by method Ba 7-58 of the American Oil Chemists Society (1975). The neutral-detergent fibre (NDF), acid-detergent fibre (ADF) and lignin contents were determined by the method of Robertson \& van Soest (1981). The crude ash, crude oil and gross energy contents of the feeds were analysed according to conventional methods (Association of Official Analytical Chemists, 1975). The amount of freeze-dried matter (FDM) collected from the terminal ileum of each rat was determined after freeze-drying the samples for $3 \mathrm{~d}$.

Amino acid composition was determined on samples of 5-7 mg using HPLC (Waters Associates, USA), using a reverse phase column and the Pico.Tag analytical method (Cohen et al. 1989). Duplicate samples were hydrolysed in $500 \mu 16 \mathrm{M}-\mathrm{HCl}$ with added phenol $(10 \mathrm{~g} / \mathrm{l})$, for $24 \mathrm{~h}$ at $110 \pm 1^{\circ}$ in glass tubes sealed under vacuum. For the determination of methionine and cystine in the samples obtained from the cottonseedkernel-based diets, separate duplicate samples were oxidized with performic acid $-\mathrm{H}_{2} \mathrm{O}_{2}$ $(90: 10, \mathrm{v} / \mathrm{v})$ before hydrolysis. Methionine and cystine in the samples obtained from the casein-based diet, and tryptophan, which was partly destroyed during acid hydrolysis, were not determined. The amino acids were detected by the fluorescence of their phenylisothiocyanate (PITC) derivatives using a programmable multi-wavelength detector (Waters $490 \mathrm{E}$, USA). Free amino acid molecular weights were used to calculate the weights of amino acids.

\section{Data analysis}

Apparent and true amino acid digestibility coefficients were calculated using the following equations:

$$
\begin{gathered}
\text { apparent amino acid (AA) digestibility } \\
(\mu \mathrm{g} / \mathrm{g} \text { FDM })
\end{gathered}=\frac{\text { dietary AA intake }- \text { ileal AA output }}{\text { dietary AA intake }},
$$

$\begin{gathered}\text { true AA digestibility } \\ (\mu \mathrm{g} / \mathrm{g} \text { FDM })\end{gathered}=\frac{\text { dietary AA intake }-(\text { ileal AA output - endogenous AA output })}{\text { dietary AA intake }}$,

$$
\text { AA output }(\mu \mathrm{g} / \mathrm{g} \text { FDM })=\left(\begin{array}{c}
\text { AA concentration in } \\
\text { ileal digesta }
\end{array}\right) \times \frac{\text { diet total chromium }}{\text { ileal total chromium }} .
$$

Endogenous amino acid flows used for calculating true amino acid digestibility coefficients in the present study were obtained in a separate but related study ( $\mathrm{Yu}$ et al. 1995c), in which endogenous ileal amino acid flows were determined in rats given diets containing graded levels of cottonseed hulls. The enzymically hydrolysed casein (EHC) ultrafiltration method (Moughan et al. 1990; Butts et al. 1991) was used in the latter work to determine 
endogenous amino acid losses. Data from the present study were subjected to ANOVA. A linear statistical model, which included terms for hulls, PEG and hulls $\times$ PEG, was initially fitted to the digestibility data for each amino acid singly, and reduction in sums of squares was used to determine levels of significance. Relevant comparisons between treatment means were made using orthogonal contrasts (Snedecor \& Cochran, 1982). Where a causeand-effect trend in the data was expected (e.g. ileal digestibility as a function of hull addition), the data ( $n$ 18) were subjected to a simple linear regression and slopes were tested for statistical significance from zero.

\section{RESULTS}

The overall mean live weight for the rats at the end of the study was 197 (SE 8.4) g. Mean feed intakes for the rats on day 13 of the study are given in Table 3. Feed intake was within the normal range for the $200 \mathrm{~g}$ body weight rat (National Research Council, 1978). Daily feed intake tended to be lower with the casein-based diet in comparison with the cottonseed-kernel-based diet, and dietary PEG addition did not affect feed intake on either diet (Table 3). On the last day of the study the rats had high feed intakes over the first two hourly meals and then consumed generally even-sized meals for the remainder of the feeding period (Table 3). The latter was important to ensure an even flow of digesta at the terminal ileum. Faeces were not detected in the gastric contents at slaughter indicating that coprophagy had not occurred at least on the last day of study.

There was a significant $(P<0.05)$ hulls $\times$ PEG interaction for amino acid digestibility for several of the amino acids. Accordingly, relevant comparisons were made between treatment means within the PEG or hull factors.

With both the casein and cottonseed-kernel-based diets, inclusion of PEG in the diet without hulls did not affect ileal DM digestibility or the apparent and true ileal digestibilities of $\mathrm{N}$ and individual amino acids (Tables 4, 5 and 6), indicating that there was no effect of PEG per se on dietary DM and protein digestibilities in the absence of CT.

With the casein-based diet, in the absence of PEG, addition of dietary cottonseed hulls $(70 \mathrm{~g} / \mathrm{kg})$ significantly depressed ileal DM digestibility $(P<0.001$; Table 4$)$ and the true ileal digestibility of total $\mathrm{N}(P<0.001)$. In the presence of hulls, dietary supplementation with PEG significantly increased ileal DM digestibility $(P<0.01)$ and the true ileal digestibility of total $\mathrm{N}(P<0 \cdot 01)$, with the values for total $\mathrm{N}$ attained being similar to those for diets not containing hulls.

Apparent and true ileal amino acid digestibilities for rats fed on the casein-based diet were significantly depressed $(P<0.05)$ by addition of dietary hulls (Table 4$)$. On average, the apparent ileal amino acid digestibility was decreased from 0.89 to 0.85 by the inclusion of $70 \mathrm{~g}$ hulls $/ \mathrm{kg}$ in the diet, and addition of PEG then restored this to 0.89 . The mean true ileal digestibility of amino acids decreased from 0.96 for the diet not containing hulls to 0.92 for the diet containing $70 \mathrm{~g}$ hulls $/ \mathrm{kg}$. When PEG was added to the diet containing hulls $(70 \mathrm{~g} / \mathrm{kg})$, the mean true ileal amino acid digestibility was restored to 0.95 . Apparent and true ileal digestibilities of all individual amino acids were similarly affected by the addition of hulls and PEG.

With the cottonseed-kernel-based diet, in the absence of PEG, inclusion of dietary hulls progressively depressed $(P<0.05)$ ileal DM digestibility and apparent ileal digestibility of total $\mathrm{N}$ for the rats (Table 5$)$ in a linear manner $(P<0.05$; Table 7$)$. Addition of dietary PEG significantly increased the apparent ileal $\mathrm{N}$ digestibility $(P<0.05)$, but did not affect ileal DM digestibility. However, the increased values for total $\mathbf{N}$ digestibility accounted for only about 67 and $50 \%$ of the depression in the ileal digestibility caused by the inclusion of different levels of dietary hulls $(23$ and $46 \mathrm{~g} / \mathrm{kg}$ ) respectively. True ileal $\mathrm{N}$ digestibility 
Table 3. Mean feed intakes of growing rats fed on casein-based or cottonseed-kernel-based diets with or without cottonseed hulls and PEG on day 13 and at hourly meals on day 14 (last day of study)*

(Mean values with their standard errors for six rats)

\begin{tabular}{|c|c|c|c|c|c|c|c|c|c|c|}
\hline \multirow[b]{2}{*}{ Diet } & \multicolumn{2}{|c|}{$\begin{array}{l}\text { Food intake } \\
\text { on day } 13 \\
(\mathrm{~g})\end{array}$} & \multicolumn{8}{|c|}{$\begin{array}{l}\text { Hourly meal intakes on day } 14 \dagger \\
(\mathrm{g})\end{array}$} \\
\hline & Mean & $\mathbf{S E}$ & 1 & 2 & 3 & 4 & 5 & 6 & 7 & Total \\
\hline \multicolumn{11}{|l|}{ Casein: } \\
\hline -PEG & 10 & $0 \cdot 3$ & $1 \cdot 4$ & 1.2 & $1 \cdot 2$ & 0.6 & 0.7 & 0.6 & 0.8 & 6.5 \\
\hline+ PEG & 9 & 0.7 & 1.4 & 1.0 & 0.9 & 0.6 & $0 \cdot 6$ & 1.0 & 1.0 & $6 \cdot 5$ \\
\hline $70 \mathrm{~g} / \mathrm{kg}$ hulls $-\mathrm{PEG}$ & 13 & 0.7 & $2 \cdot 7$ & 1.9 & 1.7 & $1 \cdot 0$ & 0.8 & 0.9 & 1.2 & $10 \cdot 2$ \\
\hline $70 \mathrm{~g} / \mathrm{kg}$ hulls + PEG & 13 & 1.5 & $2 \cdot 1$ & 1.9 & 1.6 & $1 \cdot 1$ & 0.8 & 1.2 & $1 \cdot 3$ & $10-0$ \\
\hline \multicolumn{11}{|l|}{ Cottonseed kernel: } \\
\hline -PEG & 15 & 0.7 & 3.5 & $2 \cdot 5$ & 0.6 & 0.6 & 1.2 & $2 \cdot 1$ & 1.5 & $12 \cdot 0$ \\
\hline+ PEG & 15 & 0.6 & $3 \cdot 1$ & $2 \cdot 3$ & 1.4 & $1 \cdot 0$ & 0.9 & $1 \cdot 3$ & 1.2 & 11.2 \\
\hline $23 \mathrm{~g} / \mathrm{kg}$ hulls - PEG & 15 & 1.0 & 3.4 & $2 \cdot 5$ & 1.9 & 1.7 & 0.8 & 1.4 & 1.2 & 12.9 \\
\hline $23 \mathrm{~g} / \mathrm{kg}$ hulls + PEG & 16 & 0.9 & $3 \cdot 4$ & 2.8 & 1.4 & 1.2 & 0.8 & 1.6 & 1.5 & $12 \cdot 7$ \\
\hline $46 \mathrm{~g} / \mathrm{kg}$ hulls $-\mathrm{PEG}$ & 16 & 0.9 & 3.9 & $2 \cdot 6$ & $2 \cdot 1$ & 0.7 & $1 \cdot 0$ & $1 \cdot 3$ & 1.2 & 12.8 \\
\hline $46 \mathrm{~g} / \mathrm{kg}$ hulls $+\mathrm{PEG}$ & 16 & $1 \cdot 1$ & $3 \cdot 7$ & $3 \cdot 2$ & $2 \cdot 1$ & 0.8 & 0.8 & 1.5 & 1.4 & 13.5 \\
\hline
\end{tabular}

* For details of diets and procedures, see Table 2 and pp. 684-686.

+ Day of sampling ileal digesta.

† MW 3500 .

was also linearly depressed by increased dietary hulls $(P<0.001$; Table 6$)$, and addition of PEG to the diets significantly restored this $(P<0.05$ at the $46 \mathrm{~g}$ hulls $/ \mathrm{kg}$ level $)$, but not back to the original level.

In the absence of PEG, inclusion of hulls in the cottonseed-kernel-based diet significantly reduced $(P<0.05)$ the apparent and true ileal digestibilities of all amino acids except methionine and cystine (Tables 5 and 6). The significant linear regression relationships (Table 7) indicated that as the level of dietary hull increased, in the absence of dietary PEG, the apparent and true ileal amino acid digestibilities of all amino acids except cystine and methionine decreased in a linear manner, with the slopes of the regression lines being significantly different from zero $(P<0.05)$. The coefficients of determination ranged from 0.38 to 0.85 , indicating that a considerable proportion of the variation in ileal digestibility was explained by fitting the regression model. Unlike the responses obtained with casein, adding hulls to a cottonseed-kernel-based diet depressed apparent and true ileal digestibilities of some amino acids more than others, with histidine, isoleucine, leucine, lysine, threonine and valine being the essential amino acids most depressed per unit of hulls added. Glycine was the non-essential amino acid most depressed.

In the diet with $23 \mathrm{~g}$ hulls $/ \mathrm{kg}$, supplementation with dietary PEG significantly increased the apparent and true ileal digestibilities of threonine and increased the apparent ileal digestibility of aspartic acid and proline (Tables 5 and 6). With the rate of hull addition increased to $46 \mathrm{~g} / \mathrm{kg}$, the apparent and true ileal digestibilities of cystine, leucine, isoleucine, threonine, valine, alanine and proline were significantly increased with PEG addition. However, unlike the casein-based diet, inclusion of dietary PEG in the diets containing hulls did not restore apparent and true ileal amino acid digestibilities to the same levels as found for diets not containing hulls and not all amino acids were affected similarly. Both the apparent and true ileal digestibilities of arginine, histidine, methionine, 


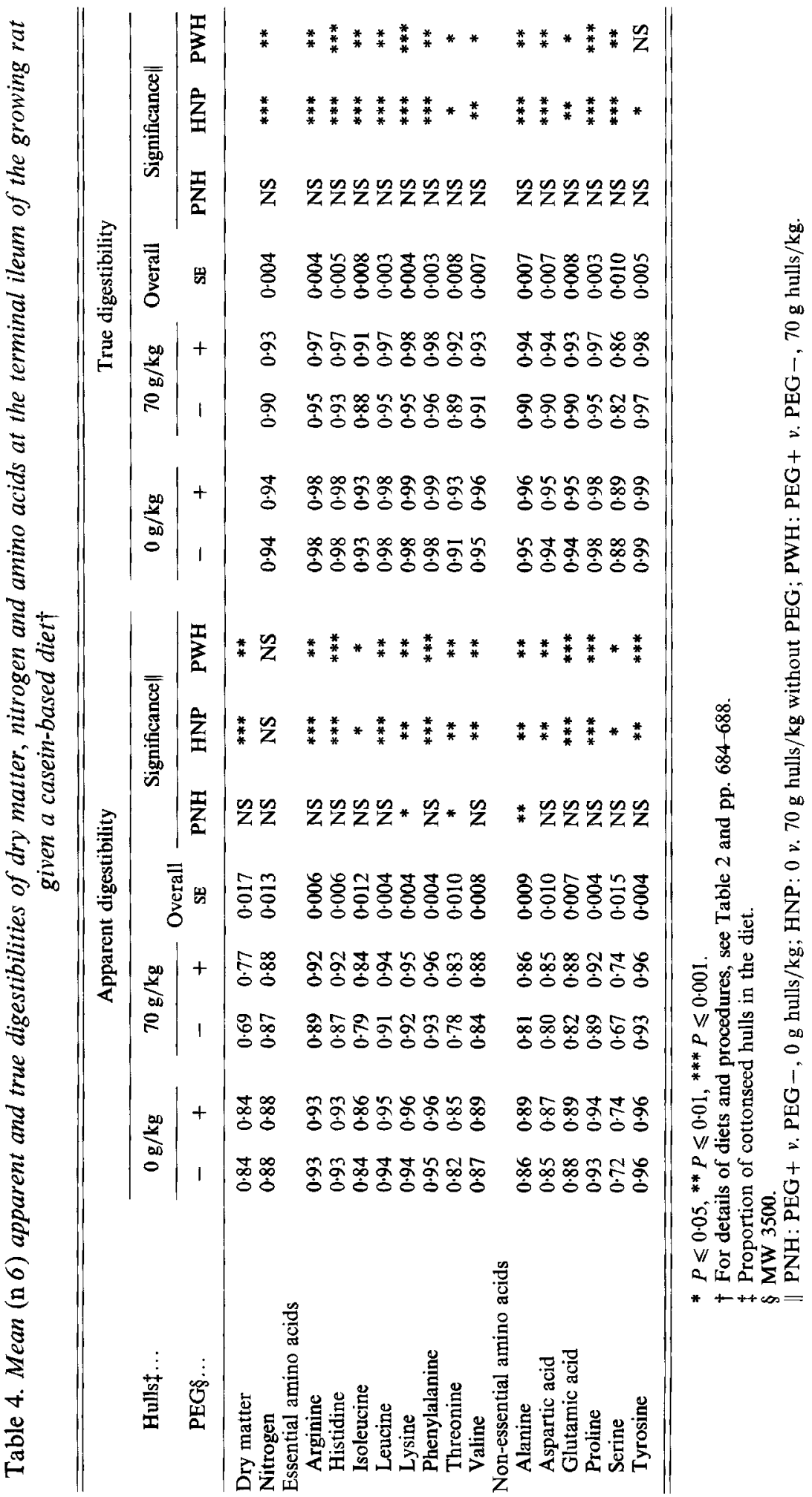


TANNINS AND AMINO ACID DIGESTIBILITY

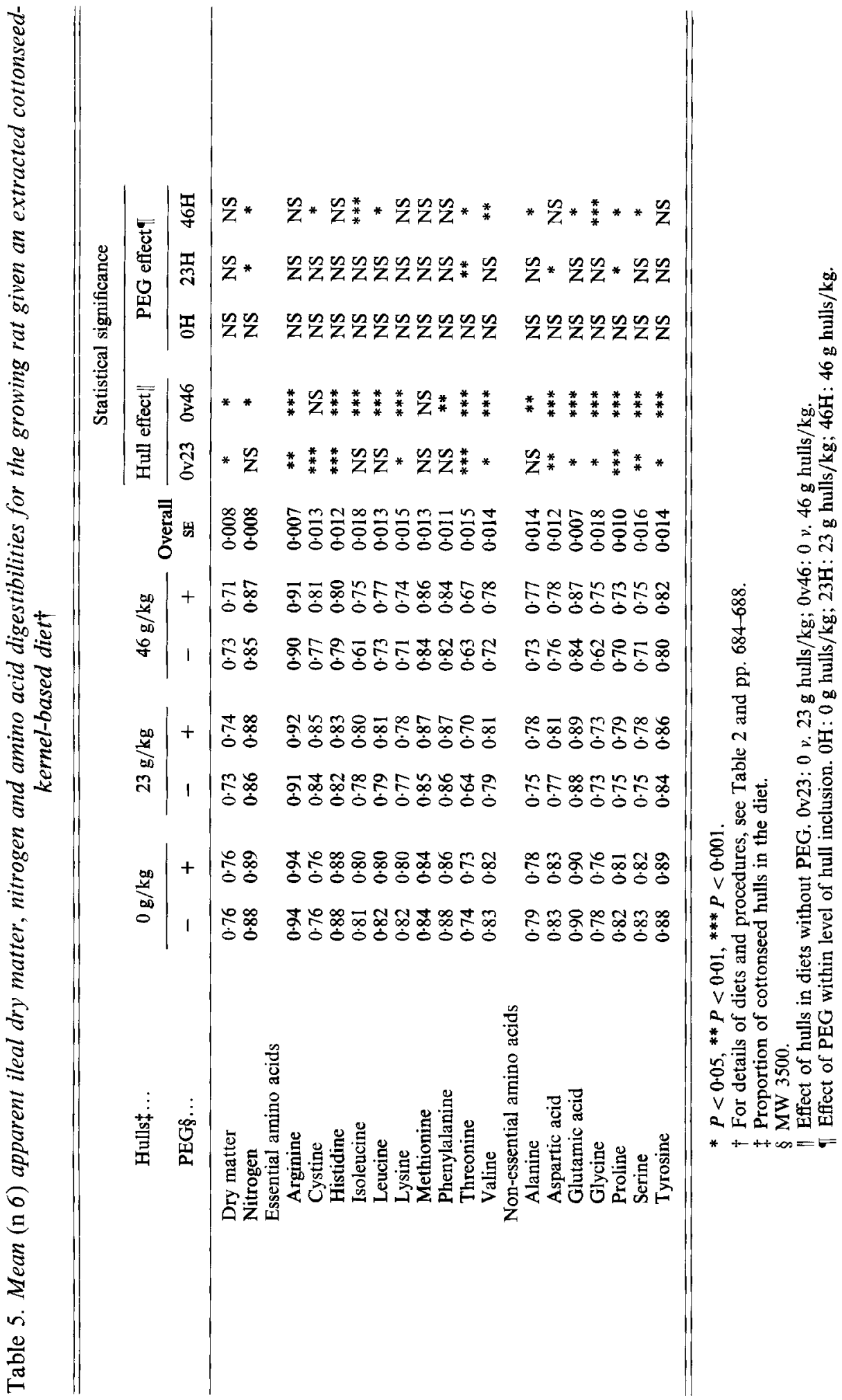




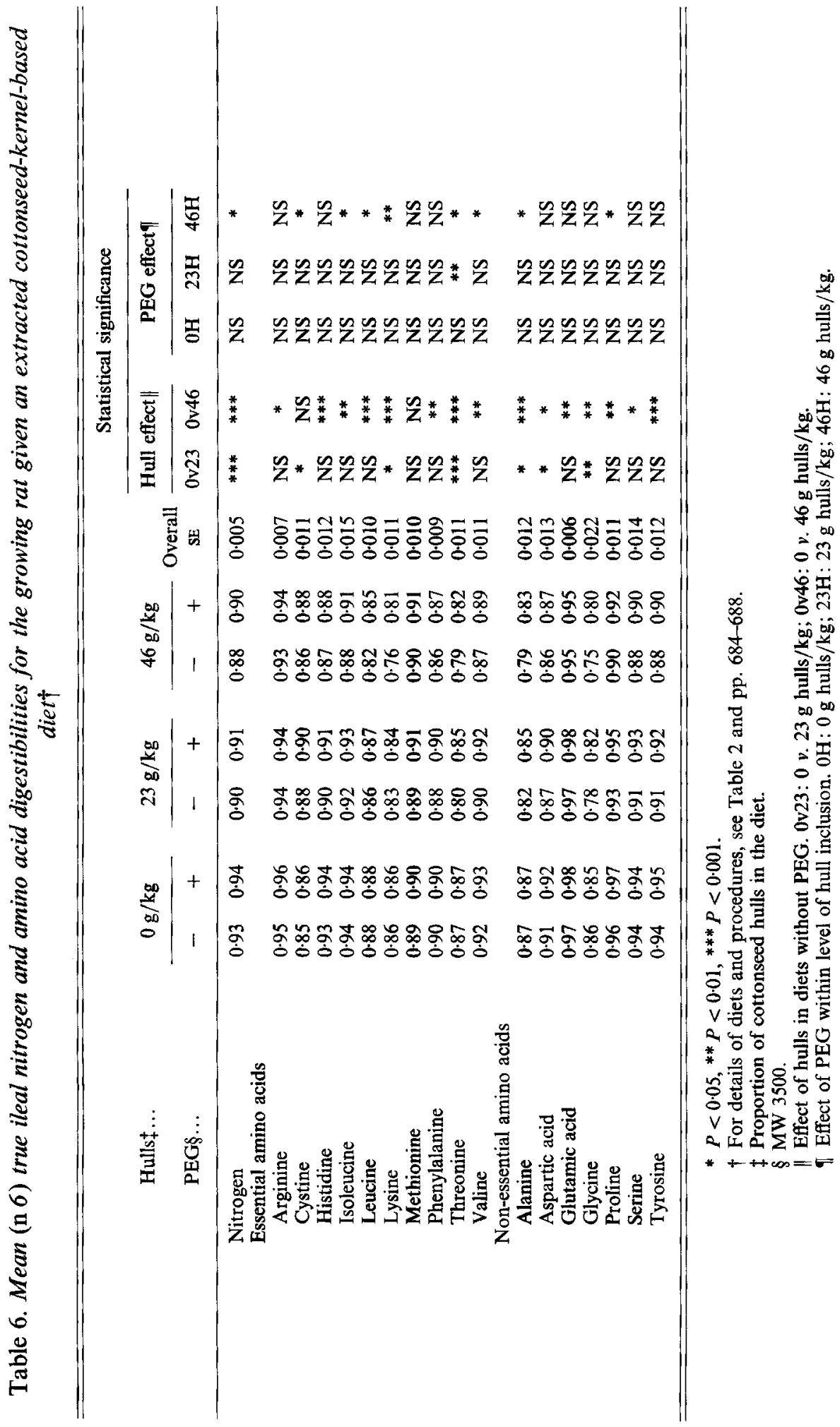


Table 7. Linear regression relationships (n 18) between ileal dry matter, nitrogen or amino acid digestibility $(\mathrm{Y})$ and hull addition $(\mathrm{x} ; \mathrm{g} / \mathrm{kg})$ for growing rats fed on an unheated solventextracted cottonseed-kernel-based diet not including $P E G$

\begin{tabular}{|c|c|c|c|c|c|c|}
\hline & \multicolumn{3}{|c|}{ Apparent ileal digestibility } & \multicolumn{3}{|c|}{ True ileal digestibility } \\
\hline & $\stackrel{\text { Linear }}{\text { regression }(Y)}$ & $R^{2}$ & $\begin{array}{c}\text { Slope } \\
\text { significance } \dagger\end{array}$ & $\begin{array}{l}\text { Linear } \\
\text { regression }(Y)\end{array}$ & $R^{2}$ & $\begin{array}{c}\text { Slope } \\
\text { significance } \dagger\end{array}$ \\
\hline Dry matter & $0.756-0.786 x$ & $0 \cdot 31$ & $*$ & & & \\
\hline Nitrogen & $0.880-0.679 x$ & 0.41 & $*$ & $0.929-1.025 x$ & 0.66 & $* * *$ \\
\hline \multicolumn{7}{|c|}{ Essential amino acids } \\
\hline Arginine & $0.936-0.893 x$ & 0.63 & $* *$ & $0.952-0.468 x$ & $0 \cdot 29$ & $*$ \\
\hline Cystine & $0 \cdot 789+0 \cdot 212 x$ & 0.01 & NS & $0.861+0.200 x$ & 0.02 & NS \\
\hline Histidine & $0.876-2 \cdot 072 x$ & 0.77 & $* * *$ & $0.935-1.469 x$ & 0.60 & $* * *$ \\
\hline Isoleucine & $0.829-4.301 x$ & $0 \cdot 74$ & $* * *$ & $0.941-1.217 x$ & 0.41 & $* *$ \\
\hline Leucine & $0.826-1.960 x$ & 0.58 & $* * *$ & $0.882-1.286 x$ & 0.59 & $* * *$ \\
\hline Lysine & $0 \cdot 817-2 \cdot 288 x$ & 0.72 & $* * *$ & $0.863-2.055 x$ & 0.69 & $* * *$ \\
\hline Methionine & $0 \cdot 847-0 \cdot 108 x$ & 0.01 & NS & $0.887-0.318 x$ & 0.06 & NS \\
\hline Phenylalanine & $0 \cdot 878-1 \cdot 186 x$ & 0.51 & $* *$ & $0.903-0.980 x$ & $0 \cdot 44$ & $* *$ \\
\hline Threonine & $0.730-2.630 x$ & 0.64 & $* *$ & $0.860-1.704 x$ & 0.57 & $* * *$ \\
\hline Valine & $0.838-2.449 x$ & 0.70 & $* * *$ & $0 \cdot 924-1 \cdot 100 x$ & 0.41 & $* *$ \\
\hline \multicolumn{7}{|c|}{ Non-essential amino acids } \\
\hline Alanine & $0.790-1.319 x$ & $0 \cdot 38$ & $*$ & $0.868-1.686 x$ & 0.43 & $* *$ \\
\hline Aspartic acid & $0.822-1.585 x$ & $0 \cdot 62$ & $* * *$ & $0.903-1.014 x$ & $0 \cdot 33$ & $*$ \\
\hline Glutamic acid & $0.901-1.297 x$ & 0.75 & $* * *$ & $0.977-0.573 x$ & 0.40 & $*$ \\
\hline Glycine & $0.783-3.197 x$ & 0.74 & $* * *$ & $0.851-2 \cdot 360 x$ & $0 \cdot 41$ & $* *$ \\
\hline Proline & $0.819-2.688 x$ & 0.85 & $* * *$ & $0.954-1 \cdot 110 x$ & 0.60 & $* * *$ \\
\hline Serine & $0.823-2.635 x$ & 0.85 & $* * *$ & $0.939-1.217 x$ & 0.56 & $* *$ \\
\hline Tyrosine & $0.876-1.712 x$ & $0 \cdot 75$ & $* * *$ & $0 \cdot 940-1 \cdot 314 x$ & 0.52 & $* *$ \\
\hline
\end{tabular}

phenylalanine, aspartic acid and tyrosine were not significantly increased by PEG addition to diets containing cottonseed hulls.

\section{DISCUSSION}

In the present study the effect of cottonseed hulls on the nutritional value of casein and unheated solvent-extracted cottonseed kernel as dietary protein sources was studied in the growing rat by determining apparent and true ileal $\mathrm{N}$ and amino acid digestibilities. The principal finding was that the inclusion of hulls depressed the apparent and true ileal digestibilities of $\mathrm{N}$ and amino acids, but with the response differing between diets. With the casein-based diet all amino acids were significantly affected and all of the depression in digestibility could be explained by the CT content of the hulls. However, with the cottonseed-kernel-based diet the responses fell into three categories. The apparent and true ileal digestibilities of the essential amino acids cystine and methionine were not affected by hull addition, ileal digestibilities of leucine, isoleucine, lysine, threonine and valine were markedly depressed by hull addition with approximately $50 \%$ of the depression being explained by CT, whilst ileal digestibilities of histidine, arginine and phenylalanine were depressed by hull addition but little or none of this effect could be explained by CT. Thus interactions with hulls, affecting amino acid digestion, clearly differed between sources of protein. With the cottonseed-kernel-based diet it seems that components of the hulls other than CT also depressed the apparent and true ileal digestibilities of $\mathrm{N}$ and amino acids. The identity of these components is unknown. 
These studies have shown the presence of hulls to be one of the reasons for the generally low levels of amino acid digestibility in cottonseed meal, due to the effect of hulls in lowering the true ileal digestibility of amino acids (present study) and in increasing endogenous ileal amino acid excretion (Yu et al. 1995c). The reduction in true ileal amino acid digestibility per unit increase in hull content for the cottonseed-kernel diets differed for each amino acid, showing that inclusion of hulls will unbalance the digestible amino acids in cottonseed meal. This seems particularly important for amino acids that are most likely to be limiting, such as lysine and threonine, whose true ileal digestibility was most lowered by hull inclusion in the cottonseed-kernel diets.

PEG has been used to absorb plant phenolics during the extraction of enzymes (Jones, 1965) and preferentially binds with CT, preventing CT from reacting with proteins or carbohydrates and displaces CT from CT:protein or CT:carbohydrate complexes (Jones \& Mangan, 1977; Barry \& Manley, 1986). If PEG is included in a CT-containing diet, the CT will still be present, but will be rendered unreactive in the digestive tract because of the preferential nature of the binding between CT and PEG (McNabb, 1991). This provides a unique way of studying the effect of the presence or absence of reactive CT, without affecting the nutritive composition of the diet. Complete control of the levels of other dietary ingredients is afforded. In the present study there was no effect of PEG addition on feed intake or apparent and true ileal protein and amino acid digestibilities in the diets not containing cottonseed hulls, thus demonstrating that PEG addition per se had no intrinsic effect on feed intake and ileal protein digestibility in the absence of CT. Similar observations on endogenous ileal amino acid loss with rats fed on an enzymically hydrolysed casein-based diet were made by Yu et al. (1995c). Yu et al. (1995b) reported that $2 \mathrm{mg} \mathrm{PEG} / \mathrm{mg}$ total CT was required to inactivate the CT in cottonseed hulls. It is thus assumed that in the present study PEG completely bound the CT released during digestion of cottonseed hulls and that for the hull-containing diets, comparisons, with or without PEG, represented effects of cottonseed CT.

Cottonseed hulls are a by-product of cottonseed processing, with the cottonseed being cleaned and partly dehulled before the kernels are crushed and subjected to oil extraction. Commercial cottonseed meal produced in Australia contains between 150 and $300 \mathrm{~g}$ hulls $/ \mathrm{kg}$ and has a CT content of $8-15 \mathrm{~g} / \mathrm{kg} \mathrm{DM}, 92 \%$ of which is bound to protein and fibre (Yu et al. 1993). Extractable CT as found in fresh forages can readily react with dietary protein during ingestion and digestion (Barry \& Manley, 1986; McNabb, 1991), but the effects of bound CT have not been previously studied in single-stomached animals. Yu et al. (1995a) found that bound CT were relatively unreactive at rumen $\mathrm{pH}(\mathrm{pH} \mathrm{7.0)}$, but the responses to PEG in diets containing cottonseed hulls in the present study suggest that CT react with proteins in the single-stomach digestive system. CT are known to be solubilized in the stomach (Jones \& Mangan, 1977) and the most probable explanation for the present result is that the bound CT in cottonseed hulls were solubilized and released in the stomach and were thus available to react with proteins in the small intestine.

The effects of CT in depressing apparent ileal protein digestibility may be explained either by a direct binding of CT to dietary proteins, by a reduced activity of proteindegrading enzymes (Longstaff \& McNab, 1991), or by increased secretion of endogenous proteins (digestive enzymes, mucus or mucosal cells; Mangan, 1988; Marquardt, 1989). However, in recent work where ileal endogenous amino acid flow was determined in the rat, no effect of CT in cottonseed hulls was found (Yu et al. 1995c).

There were differences in the apparent ileal digestibility of amino acids between casein and cottonseed kernels. In the absence of hulls the apparent ileal amino acid digestibility, except that for three amino acids (arginine, glutamic acid and serine), was markedly higher for the casein-based diet than for the cottonseed-kernel-based diet. The difference in 
apparent ileal amino acid digestibility between the two protein sources suggests a difference in the intrinsic quality of the proteins. This is confirmed by the lower true ileal amino acid digestibility in the cottonseed-kernel-based diet than in the casein-based diet (Tables 4 and 6). The relatively low digestibility of amino acids in cottonseed meal has been reported by other workers (Batterham et al. 1990; Batterham, 1992). Apparent ileal amino acid digestibility was depressed by an increase in dietary hulls in both the casein and cottonseedkernel-based diets. This effect may be due to both the CT and fibre contents of the hulls. However, ileal amino acid digestibility for the casein diet was still higher than that for the cottonseed-kernel diet, even though the level of hull addition was higher in the casein-based diet ( $70 \mathrm{~g}$ hulls $/ \mathrm{kg}$, compared with 23 and $46 \mathrm{~g}$ hulls $/ \mathrm{kg}$ in the cottonseed-based diet). With addition of PEG to the casein-based diet containing hulls, the depressed ileal amino acid digestibility was restored to almost the original level, but only about half of the decrease in digestibility was restored after PEG addition with the cottonseed-kernel-based diet. This suggests that only about half of the depression in ileal digestibility caused by hull addition to a cottonseed-kernel diet can be explained by CT, with the remainder presumably being due to unidentified reactions with other hull components.

It seems that CT may have different affinities for proteins with different amino acid profiles. Asquith \& Butler (1986), in an in vitro study, noted that CT-protein interactions may be specific for different tannins as well as for different proteins. The high degree of interaction indicated that the differences in affinity were functionally significant. Hagerman \& Butler (1981) found that Sorghum tannins have a high affinity for proteins that are relatively large, with an open, loose structure, and that are rich in hydrophobic amino acids, particularly proline. Cousins et al. (1981), in a study with sorghums containing different levels of CT, showed that the apparent ileal digestibilities of tryptophan, histidine, glycine and proline were more depressed than for other amino acids in high-tannin varieties. Differences in protein structure and composition may account for the different responses to cottonseed CT observed in the present study between casein and cottonseed kernel. In the present study the true ileal digestibilities of the essential amino acids histidine, leucine, isoleucine, lysine, threonine and valine in the cottonseed-kernel-based diets were more depressed with high levels of dietary CT compared with the other amino acids, suggesting that reactions between these amino acids and CT are not completely reversible in the small intestine.

The ileal digestibility coefficients presented here indicate that the correction of apparent ileal $\mathrm{N}$ and amino acid digestibilities for endogenous excretion, as determined by the EHC technique ( $\mathrm{Yu}$ et al. 1995c), results in true ileal $\mathrm{N}$ and amino acid digestibilities which are markedly higher (about $11 \%$ for alanine, cystine, aspartic acid, and up to $22 \%$ for serine) than corresponding apparent estimates. The ileal endogenous excretion of $\mathrm{N}$ and amino acids, determined using the recently developed peptide alimentation-digesta ultrafiltration method (Moughan et al. 1990; Butts et al. 1991), was slightly increased by the inclusion of $50 \mathrm{~g}$ cottonseed hulls $/ \mathrm{kg}$ in the EHC-based diet (Yu et al. 1995c). The authors concluded that this increase was caused by the cottonseed-hull-fibre component, and there did not appear to be an effect of CT on endogenous ileal amino acid loss. In the present study the lowered apparent ileal digestibilities of $\mathrm{N}$ and amino acids in the diets containing cottonseed hulls can be attributed to a decrease in digestion and absorption as reflected by the true coefficients of digestibility of dietary protein (Tables 4, 5 and 6) and also increased endogenous protein excretion.

The consumption of diets containing CT has been shown to increase the size of the parotid glands in the rat and the synthesis and secretion of proline-rich proteins (PRP; Mehansho et al. 1992). Tannin-induced PRP were shown to have a very high binding affinity for tannins (Mehansho et al. 1983). The mechanism by which tannins induce 
hypertrophy in the parotid glands of the rat and increase the secretion of PRP is not clear (Jansman, 1993a). Although salivas of various species contain PRP (Mole et al. 1990), it is not clear whether species other than the rat are able to develop a similar response when consuming tannin-containing diets. In the hamster this response was absent and used as an explanation for the high sensitivity of this species to dietary tannin (Mehansho et al. 1987). If pigs and poultry lack this response, the rat may not be a completely valid model for establishing the nutritional effects of dietary tannins in these commercially important animals. Thus, further experiments studying the effects of cottonseed $\mathrm{CT}$ on ileal $\mathrm{N}$ and amino acid digestibilities in pigs and poultry are necessary.

The presence of CT in the hulls is part of the host-plant resistance mechanism in cotton for defence against attack by insects and pathogenic micro-organisms (Fitt et al. 1992). It seems, on this basis, unrealistic to select for low CT levels in cotton breeding programs. Heating, as employed during commercial cottonseed meal manufacturing, may have some effect on protein solubilization. The present study was done with unheated solventextracted cottonseed, so further work is needed to study the effects of hull inclusion in the presence and absence of heat treatment, and to compare the effect of CT between animal species, notably comparing rats with pigs and poultry. If cottonseed hulls increase endogenous ileal amino acid loss ( $\mathrm{Yu}$ et al. 1995c) and depress ileal protein digestion in heated extracted cottonseed kernel to the same extent as found in the present study, then it seems that the presence of hulls in commercial cottonseed meal should be reduced to the lowest possible levels.

This study was supported by a grant from the Australian Cotton Research and Development Corporation. The authors thank Cotton Seed Distributors Ltd, Wee Waa, NSW, Australia for supplying cottonseed and Mr G. Pearson of the Monogastric Research Centre, and Ms F.S. Jackson and Mr J. A. Anderson of the Department of Animal Science, Massey University for their skilled technical assistance.

\section{REFEREN CES}

American Oil Chemists Society (1975). Official and Tentative Methods of American Oil Chemists Society, 3rd ed., pp. Ba 7-58. Champaign, IL: American Oil Chemists Society.

Asquith, T. N. \& Butler, L. G. (1986). Interactions of condensed tannins with selected proteins. Phytochemistry 25, 1591-1593.

Association of Official Analytical Chemists (1975). Official Methods of Analysis, 12th ed. Washington, DC: Association of Official Analytical Chemists.

Balogun, T. F., Aduku, A. O., Dim, N. I. \& Olorunji, S. A. S. (1990). Undecorticated cottonseed meal as a substitute for soya bean meal in diets for weaner and growing finishing pigs. Animal Feed Science and Technology 30, 193-201.

Barry, T. N. \& Manley, T. R. (1986). Interrelationships between the concentrations of total condensed tannin, free condensed tannin and lignin in Lotus sp. and their possible consequences in ruminant nutrition. Journal of the Science of Food and Agriculture 37, 248-254.

Batterham, E. S. (1992). Availability and utilization of amino acids for growing pigs. Nutrition Research Reviews 5, 1-18.

Batterham, E. S., Anderson, L. M., Baigent, D. R., Beech, S. A. \& Elliott, R. (1990). A comparison of the availability and ileal digestibility of lysine in cottonseed and soybean meals for grower/finisher pigs. British Journal of Nutrition 64, 663-677.

Berardi, L. C. \& Goldblatt, L. A. (1980). Gossypol. In Toxic Constituents of Plant Foodstuffs, pp. $183-237$ [I. E. Liener, editor]. New York, London and Sydney: Academic Press.

Butts, C. A., Moughan, P. J. \& Smith, W. C. (1991). Endogenous amino acid flow at the terminal ileum of the rat determined under conditions of peptide alimentation. Journal of the Science of Food and Agriculture 55, 175-187.

Cohen, S. A., Meys, M. \& Tarvin, T. L. (1989). The Pico.Tag Method. A Manual of Advanced Techniques for Amino Acid Analysis. Bedford, MA: Millipore Corporation.

Costigan, P. \& Ellis, K. J. (1987). Analysis of faecal chromium derived from controlled release marker devices. New Zealand Journal of Technology 3, 89-92. 
Cousins, B. W., Tanksley, T. D., Knabe, D. A. \& Zebrowska, T. (1981). Nutrient digestibility and performance of pigs fed sorghums varying in tannin concentration. Journal of Animal Science 53, 1524-1537.

Damaty, S. M. \& Hudson, B. J. F. (1979). The interaction between gossypol and cottonseed protein. Journal of the Science of Food and Agriculture 30, 1050-1056.

Fitt, G. P., Mares, C. L., Wilson, L. J. \& Thomson, N. J. (1992). Development of resistance to insects in Australian cotton varieties. In Proceedings of 1992 Australian Cotton Conference, pp. 307-322. Gold Coast, Queensland: The Australian Cotton Growers' Research Association.

Frank, A. W. (1987). Food uses of cottonseed protein. In Developments in Food Protein-5, pp. 31-80 [B. J. F. Hudson, editor]. London and New York: Elsevier Applied Science.

Griffiths, D. W. (1979). The inhibition of digestive enzymes by extracts of field beans. Journal of the Science of Food and Agriculture 30, 458-462.

Griffiths, D. W. \& Moseley, G. (1980). The effects of diets containing field beans of high or low polyphenolic content on the activity of digestive enzymes in the intestines of rats. Journal of the Science of Food and Agriculture 31, 255-259.

Hagerman, A. E. \& Butler, L. G. (1981). The specificity of proanthocyanidins - protein interactions. Journal of Biological Chemistry 256, 4494-4497.

Helsper, J. P. F. G., Hoogendijk, J. M., van Norel, A. \& Burger-Meyer, K. (1993). Antinutritional factors in Faba beans (Vicia faba L.) as affected by breeding toward the absence of condensed tannins. Journal of Agricultural and Food Chemistry 41, 1058-1061.

Huisman, J., van der Poel, A. F. B., Verstegen, M. W. A. \& van Weerden, E. J. (1990). Antinutritional factors (ANF) in pig production. World Review of Animal Production 25, 77-82.

Ikurior, S. A. \& Fetuga, B. L. A. (1988). Chemical and biological evaluation of Nigerian cottonseed meal protein quality. Animal Feed Science and Technology 20, 251-258.

Jansman, A. J. M. (1993a). Tannins in feedstuffs for simple-stomached animals. Nutrition Research Reviews 6 , 209-236.

Jansman, A. J. M. (1993b). Tannins in faba beans (Vicia faba L.) - antinutritional properties in monogastric animals, pp. 51-70. PhD Thesis, Wageningen Agricultural University, The Netherlands.

Jones, D. E. (1965). Banana tannin and its reaction with polyethylene glycols. Nature 206, 299-300.

Jones, W. T. \& Mangan, J. L. (1977). Complexes of the condensed tannins of sainfoin (Onybrychis viciifolia Scop.) with Fraction 1 Leaf protein and with submaxillary mucoprotein, and their reversal by polyethylene glycol and $\mathrm{pH}$. Journal of the Science of Food and Agriculture 28, 126-136.

Longstaff, M. \& McNab, J. M. (1991). The inhibitory effects of hull polysaccharides and tannins of field beans (Vicia faba L.) on the digestion of amino acids, starch and lipid and on digestive enzyme activities in young chicks. British Journal of Nutrition 65, 199-216.

Lusas, E. W. \& Jividen, G. M. (1987). Glandless cottonseed, a review of the first 25 years of processing and utilisation research. Journal of the American Oil Chemists' Society 64, 839-854.

Lyman, C. M., Baliga, B. P. \& Slay, M. W. (1959). Reactions of proteins with gossypol. Archives of Biochemistry and Biophysics 84, 486-497.

McNabb, W. C. (1991). Digestion and metabolism of sulphur containing amino acids in sheep fed fresh forage diets. PhD Thesis, Massey University, Palmerston North, New Zealand.

Mangan, J. L. (1988). Nutritional effects of tannins in animal feeds. Nutrition Research Reviews 1, $209-231$.

Marquardt, R. R. (1989). Dietary effects of tannins, vicine and convicine. In Recent Advances of Research in Antinutritional Factors in Legume Seeds, pp. 141-155 [J. Huisman, A. F. B. van der Poel and I. E. Liener, editors]. Wageningen: Pudoc.

Martinez, W. H., Beradi, L. C., Frampton, V. L., Eilcke, H. L., Green, D. E. \& Teichman, R. (1967). Importance of cellular constifuents to cottonseed meal protein quality. Journal of Agricultural and Food Chemistry 15, 427-432.

Mehansho, H., Ann, D. K., Butler, L. G. \& Carlson, D. M. (1987). Induction of proline-rich proteins in hamster salivary glands by isoproterenol treatment and an unusual growth inhibition by tannins. Journal of Biological Chemistry 260, 4418-4423.

Mehansho, H., Asquith, T. N., Butler, L. G., Rogler, J. C. \& Carlson, D. M. (1992). Tannin-mediated induction of proline-rich protein synthesis. Journal of Agricultural and Food Chemistry 40, 93-97.

Mehansho, H., Hagerman, A., Clements, S., Butler, L. G., Rogler, J. C. \& Carlson, D. M. (1983). Modulation of proline-rich protein biosynthesis in rat parotid glands by sorghum with high tannin levels. Proceedings of the National Academy of Sciences USA 80, 3948-3952.

Mitjavila, S., Lacombe, C., Carrera, G. \& Derache, R. (1977). Tannic acid and oxidised tannic acid on the functional state of rat intestinal epithelium. Journal of Nutrition 107, 2113-2121.

Mole, S., Butler, L. G. \& Iason, G. (1990). Defence against dietary tannin in herbivores: a survey for proline rich salivary proteins in mammals. Biochemical Systematics and Ecology 18, 287-293.

Moughan, P. J., Darragh, A. J., Smith, W. C. \& Butts, C. A. (1990). Perchloric and trichloroacetic acids as precipitants of protein in endogenous ileal digesta from the rat. Journal of the Science of Food and Agriculture 52, 13-21. 
National Research Council (1978). Nutrient requirements of the laboratory rat. In Nutrient Requirements of Laboratory Animals, pp. 7-32. Washington, DC: National Research Council.

Pons, W. A. \& Eaves, P. H. (1967). Aqueous acetone extraction of cottonseed. Journal of the American Oil Chemists Society 44, 460-464.

Robertson, J. B. \& van Soest, P. J. (1981). The detergent system of analysis and its application in human food. In The Analysis of Dietary Fibre in Food, pp. 123-158 [W. P. T. James and O. Theander, editors]. New York and Basel: Marcel Dekker, Inc.

Salunkhe, D. K., Chavan, J. K. \& Kadam, S. S. (1990). Dietary Tannins: Consequences and Remedies. Chapter 5. Nutritional Consequences of Dietary Tannins, pp. 113-146. Boca Raton, FL: CRC Press.

Sell, D. R., Reed, W. M., Chrisman, C. L. \& Rogler, J. C. (1985). Mucin excretion and morphology of the intestinal tract as influenced by sorghum tannins. Nutrition Reports International 31, 1369-1374.

Snedecor, G. W. \& Cochran, W. G. (1982). Statistical Methods. Ames, IA: Iowa State University Press.

Terrill, T. H., Rowan, A. M., Douglas, G. B. \& Barry, T. N. (1992). Determination of extractable and bound condensed tannin concentrations in forage plants, protein concentrate meals and cereal grains. Journal of the Science of Food and Agriculture 58, 321-329.

Thomsen, L. (1981). Bowl for feeding powdered diets to rats. Laboratory Animals 15, 177-178.

van Leeuwen, P., Koninkx, J. F. J. L., Jansman, A. J. M. \& Mouwen, J. M. V. M. (1993). Effect of condensed tannins in hulls of Faba beans (Vicia faba L.) on some morphological and functional parameters of small intestinal mucosa of piglets. In Recent Advances of Research in Antinutritional Factors in Legume Seeds, pp. 335-339 [A. F. B. van der Poel, J. Huisman and H. S. Saini, editors]. Wageningen: Wageningen Pers.

Varnish, S. A. \& Carpenter, K. L. (1975) Mechanism of heat damage in proteins. 5. The nutritional values of heatdamage and propionylated proteins as sources of lysine, methionine and tryptophan. British Journal of Nutrition 34, 325-337.

Yu, F., Barry, T. N., McNabb, W. C., Moughan, P. J. \& Wilson, G. F. (1995a). Effect of bound condensed tannin from cottonseed upon in situ protein solubility and dry matter degradation in the rumen. Journal of the Science of Food and Agriculture 69, 311-319.

Yu, F., Barry, T. N., Moughan, P. J. \& Wilson, G. F. (1993). Condensed tannin and gossypol concentrations in cottonseed and in processed cottonseed meal. Journal of the Science of Food and Agriculture 63, 7-15.

Yu, F., McNabb, W. C., Barry, T. N. \& Waghorn, G. C. (1995b). Effect of condensed tannin in cottonseed hulls upon the in vitro degradation of cottonseed kernel proteins by rumen micro-organisms. Journal of the Science of Food and Agriculture 69, 223-234.

Yu, F., Moughan, P. J. \& Barry, T. N. (1995c). Effect of condensed tannin in cottonseed hulls on endogenous ileal amino acid loss in the growing rat. Journal of the Science of Food and Agriculture 68, 451-455. 